\title{
ISTIHSAN METHODOLOGY IN THE PRODUCTIVE WAQF APPLICATION
}

\author{
SUDIRMAN SUPARMIN \\ UIN Sumatera Utara, Medan \\ Email: sudirman.suparmin@uinsu.ac.id
}

\begin{abstract}
Istihsan is a form of ijtihad method by calculating the law of a problem so that it is better for certain reasons as long as it does not violate Islamic law. Istihsan based on the argument used is divided into three: first, switching from qiyas dzahir to qiyas khafi; second, switching from general propositions to specific characteristics; third from Kulli's law to exceptions to legal exclusion (exceptions). Meanwhile, based on the backrest taken by mujtahid divided into four types; istihsan qiyasi, istihsan nashi, istihsan bi al-'urf and istihsan dharuri. Earning cash in the form of cash is a new phenomenon that is still often debated about its legality as a solution of the Islamic religion. This paper explains the role of istihsan methodology in restoring contemporary economic activities in the form of productive endowments. Based on its practices and functions, cash waqf has enormous benefits for the economic progress of the community. With the analysis of the istihsan methodology, it can be seen that the cash waqf law is permissible to review using the istihsan bi al-'urf approach.
\end{abstract}

Keywords: Istihsan Methodology, Productive Waqf Application

\section{Abstrak}

Istihsan adalah bentuk metode ijtihad dengan menghitung hukum suatu masalah sehingga lebih baik untuk alasan-alasan tertentu selama tidak melanggar hukum Islam. Istihsan berdasarkan argumen yang digunakan dibagi menjadi tiga: pertama, beralih dari qiyas dzahir ke qiyas khafi; kedua, beralih dari proposisi umum ke karakteristik khusus; ketiga dari hukum Kulli hingga pengecualian hingga pengecualian hukum (pengecualian). Sementara itu, berdasarkan sandaran yang diambil oleh mujtahid dibagi menjadi empat jenis; istihsan qiyasi, istihsan nashi, istihsan bi al-'urf dan istihsan dharuri. Menghasilkan uang tunai dalam bentuk uang tunai adalah fenomena baru yang masih sering diperdebatkan tentang legalitasnya sebagai solusi dari agama Islam. Makalah ini menjelaskan peran metodologi istihsan dalam memulihkan kegiatan ekonomi 


\section{Fitrah \\ $\triangle$ Jurnal Kajian Ilmu-ilmu Keislaman \\ Vol. 6 No. 1 June 2020}

kontemporer dalam bentuk dana abadi produktif. Berdasarkan praktik dan fungsinya, wakaf tunai memiliki manfaat besar bagi kemajuan ekonomi masyarakat. Dengan analisis metodologi istihsan, dapat dilihat bahwa hukum wakaf tunai diizinkan untuk ditinjau menggunakan pendekatan istihsan bi al-ururf.

Kata kunci: Metodologi Istihsan, Aplikasi Wakaf Produktif

\section{INTRODUCTION}

Islam is a moral religion. The teachings he delivered were not only aimed at overcoming the weaknesses of social structure, but also aimed at realizing social welfare for the community. He taught Muslims a charitable concept that would not break their reward even though the person who did charity had died. The concept is a representative practice which is a feature of the charity that has social and economic value that will contribute to the welfare of the lives of Muslims. Besides aiming to strengthen the ties of fellow Muslims, waqf also helps alleviate the suffering faced by the poor and disadvantaged groups.

Following history, the first practice of waqf in Islam occurred in the third year of Hijrah. It was carried out by Mukhayrik al-Yahuddiyyi, a Jewish national who participated with the Prophet Muhammad in the battle of Uhud. He was determined to hand over a garden full of fruit to the Messenger of Allāh dan and the Muslims if he was sacrificed in the battle of Uhud. (Ibn Hāshim : 38)

In general, the form of waqf property for some Muslims today is still limited to the endowment of immovable objects such as land and buildings. The case causes waqf has not been able to provide maximum results for the welfare of Muslims. In fact, endowment activities have evolved to new forms related to current issues, namely productive endowments. In addition to utilizing the waqf lands that have been issued, it can also be done by practicing the types of waqf that are popular today such as cash waqf (waqf / waqf al-nuqud), investment waqf and stock waqf. (Didin Kaem , 2007)

The purpose of productive endowments is endowments that may be attempted to produce a larger amount and economic value. It is also understood as endowment which is not limited to immovable objects, but extends to transferred objects such as money, securities, vehicles, intellectual property rights, leases and other transfer objects in accordance with Islamic regulations and laws. (Uswatun Hasanah, 2005) 
Contemporary fiqh phenomena such as productive endowments, will not be separated from the validity of these activities in terms of sharia. Islam with two sources of reference (theorem naqli and theorem 'aqli) provides a very broad scope in determining istinbat (conclusions) of each law of contemporary activities such as productive endowments. However, the most significant method in analyzing the activities of productive waqf is to use the methodology of the argument 'aqli in the form of istihsan.

Put simply, istihsan can be interpreted as following something better or looking for something better to follow because it was told to do so. Some schools of thought have differences of opinion regarding the use of istihsan as legal proposition. Nevertheless, despite these differences of opinion, the methodology of istihsan for most contemporary scholars is very important in formulating a concept of practice for the mujtahids. Therefore, the istihsan methodology in this paper becomes the main discussion topic in analyzing the application of productive waqf development, apart from the four reference sources; namely alQuran, al-Sunnah, Ijma and Qiyas.

\section{THE PRODUCTIVE WAQF THEORY}

\section{Definition of Waqf}

Productive Waqf comes from two words, namely waqf and productive.

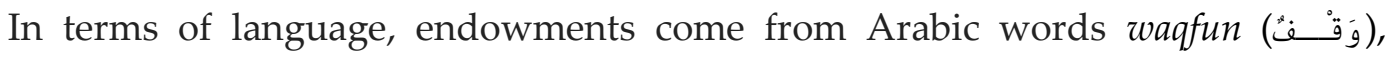
namely form masdar (infinitive noun) from greeting waqfu al-shay' (الـشَّيْءِ which carries the intention of holding back something. (Muhammad

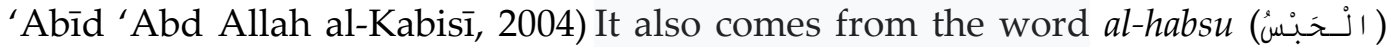

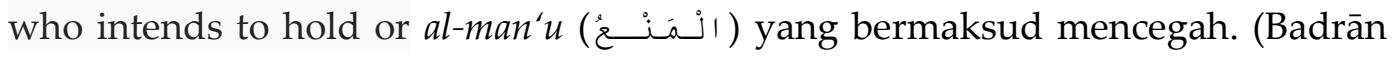
Abū al-'Aynayn Badrān, 1982)

Ibn Manzur in Lisan al-rArab defines waqf in language by standing or stopping. Waqf if it is associated with property means the purpose of withholding property rights for certain benefits. Therefore, the meaning of waqf in language is giving up land to poor people to be detained. Understood thus because their property is held and held by other people such as detaining animal animals, land and others.

The endowments according to the terms have been defined by the scholars with various definitions. Jumhur ulama define waqf as freezing one's wealth to be used by others (Wahbah al-Zuhayli, 1985). The treasure that is 


\section{Fitrah \\ $\triangle$ Jurnal Kajian Ilmu-ilmu Keislaman \\ Vol. 6 No. 1 June 2020}

represented must be in good condition and the purpose of it is to give virtue to others and draw closer to Allah SWT.

Shafi'iyyah defines waqf with various purposes. Imam Nawawi believes that waqf is withholding property that can be utilized by the public and the benefits of the object are for good and draw closer to Allah SWT (Al-Munāwī, 709/5581). Hanafiyyah pula mendefinisikan waqf dengan berbagai makna, (Muhammad 'Abīd 'Abd Allāh al-Kabisī, 2004: 47) antaranya Imām Sharkhasī yang mengatakan bahwa waqf adalah menahan harta dari pemilikan orang lain. (Al-Sharkhasī: 27)

Whereas Mālikiyyah has different opinions in understanding waqf (Muhammad al-Khurashī: 78). The majority of them argue that the endowment is the provision of benefits of an individual's property to people who deserve it with a certain contract (sighah) within the period specified by the individual (Muhammad al-Sharbinī al-Khatīb, 1958:276). When Ibn Qudāmah from the Hanbalī school defines waqf as withholding the gifts and giving away the results. (Abū Muhammad bin 'Abd Allāh bin Ahmad bin Muhammad bin Qudāmah, 1972:3)

The Zaidiyyah group also defines waqf with different purposes (Ahmad bin Qāsim al-Unsi al-Yaman̄̄ al-Sun'ānī, 1947: 281). Abū al-Qasim, author of al-Shifa 'outlines waqf as quoted by Ibn Miftah ${ }^{1}$ as a unique possession in a unique way and with the intention of drawing closer to God. (Abū al-Hasan 'Abd Allāh bin Miftāh : 458)

Another meaning of waqf according to some scholars ${ }^{2}$ as stated by Sayyid Sābiq is to hold substances (origin) of objects and use their benefits in the way (religion) of God. (Sayyid Sābiq, 1971: 378)

\footnotetext{
${ }^{1}$ Beliau adalah 'Abd Allāh Abū al-Qāsim Abū al-Hasan bin Miftāh, seorang pakar fikah mazhab Zaidiyyah yang zuhud dan wafat pada tahun $877 \mathrm{H}$.

2 Antaranya Imām Taqy al-Dīn yang mendefinisikan wakaf dari segi istilah dengan menahan harta yang dapat diambil manfaatnya. Zat (asal) harta tersebut mesti tetap dan tidak boleh dipindahkan. Harta wakaf tersebut mesti dimanfaatkan bagi tujuan kebaikan dan mendekatkan diri kepada Allah SWT, lihat Abū Bakr bin Muhammad Taqy al-Dīn (t.t), Kifayat al-Akhyar fi Hali Ghayat al-Ikhtisar. Kairo: Ahmad bin Sa'id Nabham, h. 319; Sementara Al-Muhaqqiq al-Hullī dari kalangan Ja'fariyyah mentakrifkan wakaf sebagai akad yang hasilnya adalah menahan asal benda dan memberikan manfaatnya, lihat Ja'far bin al-Hasan bin Ab̄̄ Zakariyyā Yahya bin alHasan (w.676 H), Sharai' al-Islam, j. 1. Beirut: Dār Maktabah al-Hayāh, h. 246; Muhammad Abū Zahrah pula mentakrifkan wakaf dengan maksud menahan 'ain (asal) sesuatu harta dan menyalurkan hasilnya, atau menahan 'ain (asal) sesuatu harta dan menyedekahkan manfaatnya, lihat Muhammad Abū Zahrah (1959), Muhadarat fi al-Waqf. Beirut: Jāmi'ah al-Dār al-Fikr al'Arabī, h. 7; Manakala Muhammad al-Husnī mendefinisikan wakaf dengan maksud menahan barang dan memberikan hasilnya, lihat Hidayat al-Anam li Sharī'ah al-Islam, j. 2, h. 227.
} 
Referring to the definitions of the scholars about waqf, it can be concluded that the practice of waqf has caused the loss of the right to use for the endowment (waqif) and take advantage of the assets represented. Therefore, the endowment (waqif) does not have any rights to the assets represented, and the property rights have been returned to Allah SWT. However, the endowment (waqif) will receive rewards on a continuous basis as long as the endowments are utilized for the purpose of virtue.

\section{Purpose of Productive Waqf}

It has been understood in terms of language that productive endowments are endowments that may bring a greater amount and economic value (Mahmud bin Bakyr, 2003: 2141). Therefore, productive endowments contain a broad understanding. It includes waqf lands intended to foster various lay services and ease of principles in the fields of education, health, social services and others (Departemen Agama Republik Indonesia, 2005). It also includes cash waqf (waqf / waqf al-nuqūd) which has been practiced since the beginning of the second century Hijrah and its implementation in Indonesia was only inaugurated in mid-May 2002 by the Indonesian Ulema Council (MUI). When the law on cash waqf was only passed by the president of the Republic of Indonesia on October 27, 2004 in Jakarta. (Departemen Agama Republik Indonesia, 2006:8)

Productive Waqf also includes an investment waqf which was first inaugurated on August 3, 2004 in Jakarta as a form of cooperation between the Dompet Dhuafa Institute and PT. Batasa Capital, a financial services company owned by Islamic mutual funds (Roy Hendrajanto, 2004). It is also understood as a waqf for shares, namely waqf in the form of securities which are ratiosly indicted by the Indonesian Ulema Council (MUI). The way to implement this waqf is to invest capital through the purchase of shares and the results of the capital gains will be taken every year without losing the first capital. (Wakaf Saham, 2006)

However, the purpose of productive endowments in this study will focus on cash waqf and waqf land that may provide benefits and generate added value to the endowment funds as endowments. This is because, both types of waqf have provided glory in helping the poor and poor in the study area. 


\section{Fitrah \\ $\underline{\text { Jurnal Kajian Ilmu-ilmu Keislaman }}$ \\ Vol. 6 No. 1 June 2020}

As for the terms, productive endowments have been defined by several Indonesian economic experts. Didin Hafidhuddin said that productive endowments are giving something in the form that can be cultivated for the virtue and benefit of the people such as money, securities and others. (Mohamad Rizki, 2006)

Uswatun Hasanah also, Chair of the Institute of Islamic Studies and Islamic Law, University of Indonesia (UI), Indonesia, defines productive endowments as endowments that are not limited to non-transferable objects, but extend to transferred objects such as money, precious metals, securities, vehicles, intellectual property rights, leases and other transfer objects that comply with sharia and legal provisions. (Uswatun Hasanah, 2005)

When the Indonesian Ulema Council (MUI) had stated on April 26, 2002 that productive endowments in the form of cash money were endowments made by individuals, groups, institutions or legal entities in the form of cash money. Included in the notion of money are securities and others. (Abdul Ghofur Anshori, 2005:90)

\section{Legal Basis for Earning Waqf}

The basis of productive waqf law and the source of waqf law in general are the same. The legal basis is referred to al-Quran, hadith and ijmak ulama. Between the verses of the Koran relating to the purpose of productive endowments are:

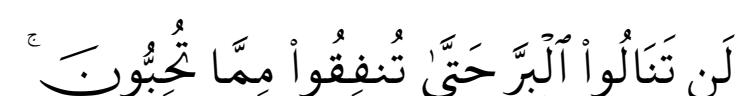

Meaning: "You never arrive at the (perfect) goodness before you spend a portion of the treasure you love." Surah Āli 'Imrān (3): 92. (Yayasan Penyelenggara Penterjemah, 1993:91)

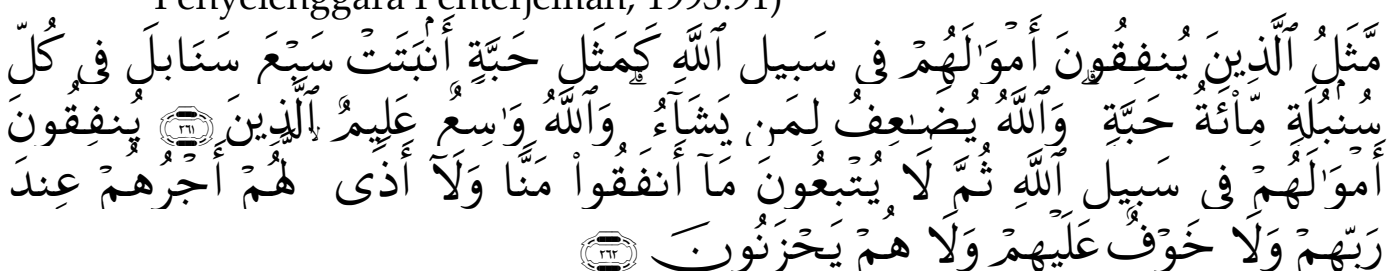

Meaning: "The parable of those who spend their wealth in the way of Allah is similar to a seed that grows seven stalks. Each stalk contains one hundred seeds. And (remember) Allah will double the rewards for whomever He wills, and Allah is vast (His blessing) is All-knowing." "Those who spend their wealth in the way of Allah, then they do not 
accompany what they spend by mentioning their gifts, and by not hurting (the feelings of those who receive), they will get a reward in the sight of their Lord. There is no concern for them and they are not sad." Surah al-Baqarah (2): 261-262

The Prophet's hadith which underlies the productive waqf includes the hadith narrated by Imam Bukhārī from Ibn 'Umar ra that' Umar ra had come to the Prophet (PBUH) to ask for guidance on the land he had acquired on Khaybar. The hadith text is:

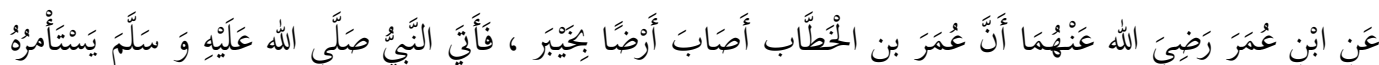

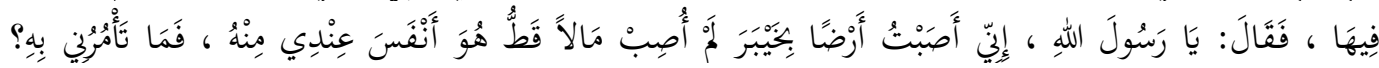

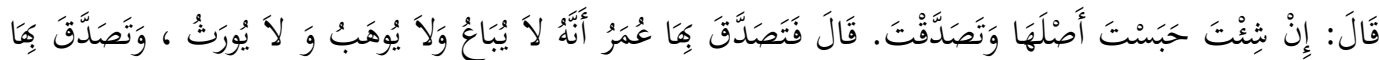

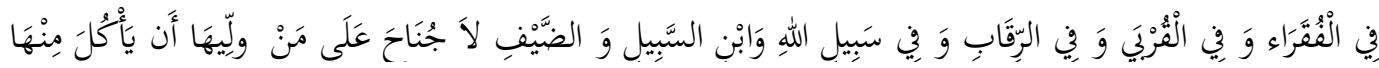

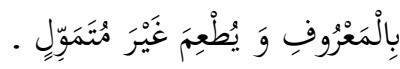

(Muhammad bin Isma'il Abu 'Abd Allah al-Bukhari al-Ju'fi,

Meaning: It was narrated from Ibn 'Umar ra that' Umar bin Khattab ra obtained land (gardens) on the earth of Khaybar. Then he came to the Prophet (PBUH) to ask for guidance regarding the land. Said "Umar ra:" O Messenger of Allah, I have acquired the land on Khaybar, never before have I received a treasure of higher value (more than that land). What will you command me about it? " The Prophet peace be upon him said: "If you wish, freeze the source (the origin of the treasure) and you give (the result)". 'Umar then offered it by not being sold, beebrown and not bequeathed either. He ('Umar) offered the results to the poor, families, slaves (oppressed people), people who fought in the way of Allah, travelers and for guests. However, it may be used in an ordinary way by those who manage it such as eating or feeding friends without making it personal property (source of wealth)."

In addition, the hadith narrated by Imam Bukhari from Abū Hurayrah may describe productive waqf. Word of the Prophet Muhammad:

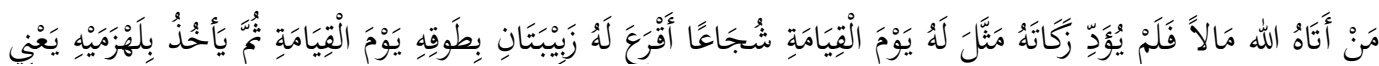

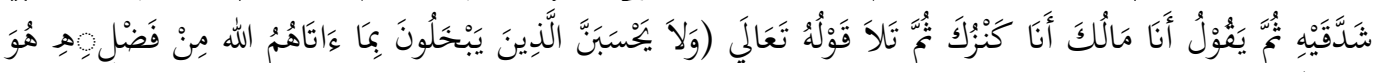
خَيْرًا فَّمْْم).

(Muhammad bin Isma'il Abu 'Abd Allah al-Bukhari al-Ju'fi, 1987:508)

Meaning: "Anyone who is given by Allah the treasure then does not issue his zakat, later on the Day of Judgment will turn into a one-eyed snake that wraps around his master's neck and then holds his ears while saying, "I am your treasure, I am your money (whose rights you do not give to 


\section{Fitrah \\ $\underline{\text { Jurnal Kajian Ilmu-ilmu Keislaman }}$ \\ Vol. 6 No. 1 June 2020}

those who are entitled accept it) ". He then reads the word of God: (Do not those who are devoted to the treasures that God has given them from His blessings think that righteousness is good for them)."

In addition, the legal basis for productive endowments is the agreement of the scholars (ijma'). ${ }^{3}$ Imam Bukhārī narrated that Imam al-Zuhrī (d. 124 AH), a prominent scholar and founder of tadwin al-Hadīth had decreed a fatwa that the endowment of the legal dinar must (mubah). The trick is to make the dinar as business capital and the profits will be distributed to the poor (wantquf 'alaih). Imam al-Zuhri encouraged the Muslim community at that time to represent the dinar and dirham for the construction of da'wah, social and educational infrastructure for Muslims. (Abu Su'ud Muhammad, 1997:20-21)

\section{RESEACRH METHOD}

This method consists of two methods; data collection methods and data analysis methods. Data collection is done through the library method. To get an information about the concept of productive waqf theory and istihsan, the author refers to several sources such as books that have been published both in Arabic and Indonesian, as well as several articles. As for knowing about the legal basis for productive endowments and istihsan, the author refers to the Koran, the Hadith of the Prophet and some Arabic books both classic and contemporary books.

Data analysis in theoretical studies will use a comparative method. This was done with a view to comparing the theories of the early Muslims and the current

\footnotetext{
${ }^{3}$ Pendapat tersebut antara lain adalah Mutaqaddimūn dari kalangan mazhab Hanafĩ yang membolehkan wakaf wang dinar dan dirham sebagai pengecualian atas dasar adat tempatan yang berlaku (Istihsān bi al-'Urf). Hal ini adalah berdasarkan pendapat 'Abd Allāh bin Mas'ūd r.a. bahwa apa yang dipandang baik oleh kaum Muslimin maka pada pandangan Allah adalah baik, dan apa yang dipandang buruk oleh kaum Muslimin maka dalam pandangan Allah adalah buruk; lihat Wahbah al-Zuhaylī (1985), op. cit., j. 8, h. 162. Abū Thaur pula, seorang ulama mazhab Shāfi'ī telah meriwayatkan dari imam Shāfi'ī tentang bolehnya wakaf menggunakan dinar dan dirham (wang); lihat al-Māwardī (1994), al-Hāwi al-Kabìr, j. 9. Beirut: Dār al-Fikr, h. 379. Fatwa Majlis Ulama Indonesia (MUI) pada 11 Mei 2002 bahwa wakaf wang tunai (cash waqf/waqf alNuqūd) adalah wakaf yang dilakukan oleh seseorang, kelompok, institusi atau agensi hukum dalam bentuk wang tunai. Termasuk ke dalam pengertian wang adalah surat-surat berharga. Wakaf wang tunai hukumnya harus/boleh (jawāz). Dan wakaf wang tunai hanya dapat disalurkan untuk perkara-perkara yang dibolehkan secara agama (shar'i) dengan menjamin keabadian asal wakaf wang tersebut tanpa menjual, menghebahkan atau pun mewariskannya; lihat Lilis (2004), op. cit. Dan sheikh Islam Ibn Taimiyah dalam bukunya al-Fatawa meriwayatkan satu pendapat dari kalangan Hanabilah yang membolehkan wakaf dalam bentuk wang, dan perkara yang sama turut dikatakan oleh Ibn Qudamah dalam bukunya al-Mughni; lihat Ibn Taimiyah (1386 H), Fatawa alKubra, j. 31. Beirut: Dar al-Ma'rifat, hh. 234-235 dan Ibn Qudamah (1972), op. cit., hh. 229-230.
} 
theories in the management of productive endowments. The results of the comparative method will be analyzed using the istihsan methodology to obtain legal status from contemporary productive waqf activities.

\section{RESULT AND DISCUSSION}

\section{The Meaning Of Istihsan}

Istihsan is etymologically a form of masdar استحسن which means to think something good (Umar Hubeis dan A. Yazid, 1985:187). Or think something is good (Badran Abu al-'Ainaini Badran, 263). Abu Hanifah still uses the meaning of lughawi as the basis for using istihsan استحسن (astahsin) i mean good.

From the etymological understanding, it is illustrated that someone has faced two things that are both good, but there are things that encourage him to leave one of them and decide to take the other because it is considered better to be practiced.

As for the term istihsan understanding, there are several definitions formulated by some usul experts:

1. Ibnu Subki proposed two definitions, namely: Switching from the use of a qiyas to another qiyas that is stronger than him. (first qiyas). (Amir Syarifuddin, 1999:305)

2. The term istihsan among the Hanafiyah Ulema as quoted by al-Sarkhasi. Charity with ijtihad and general opinion in determining something shara 'gives it to us. (Amir Syarifuddin, 1999:307)

3. Istihsan according to Malikiyah scholars among them as stated by alSyatibi. (Abi Ishaq al-Syatibi: 30 )

From some of the definitions that have been put forward by the ulama, there can be found the essence of istihsan there are two: (Nasroen Harun, 1996:105)

1. Comment qiyas khafi from qiyas jali because there is an argument that supports it.

2. Imposing the exemption of the juz'iyah law from the Kulli law or general rules, based on the special arguments that support it.

\section{Analysis Of Istihsan Methodology In The Application Of Productive Waqf}

The scholars of fiqh disagree about the validity of istihsan as the main argument in the taking of law. Among the scholars who most strongly defended 


\section{Fitrah \\ $\triangle$ Jurnal Kajian Ilmu-ilmu Keislaman \\ Vol. 6 No. 1 June 2020}

and practiced istihsan as hujjah were the Hanafi School of Law scholars, plus a number of other scholars from the Maliki and Hanbali schools. It's just that the Syafi'i School of thought scholars have different views in positioning istihsan as the main argument in taking the law.

However, there is actually no significant difference between the views of ulama who defend and support istihsan and ulama who oppose istihsan. They do not disagree in the use of lafaz istihsan, because the word which contains the meaning of hasan (good) is found in the text of the Koran and al-Sunnah. Allah SWT says in QS. Al-Zumar (39) verses 17-18 which means: "And those who stay away from taghut (ie) do not worship it and return to Allah, for them glad tidings; therefore convey the news to my servants. Those who listen to latu's words follow what is best among them. These are the people whom Allah has instructed, and those who are resourceful."

This sub-topic describes comparatively based on the opinions of the scholars regarding productive waqf law with analysis using the istihsan methodology.

Muhammad bin Abdullah al-Anshori, a student of Zufar, Abu Hanifah's best friend, may be in the form of cash both in the dirham and dinar, and in the form of commodities that can be weighed or measured, such as wheat. He explained by saying: "We invest the funds in a mudharabah manner and we turn the profits into a mudharabah business then the proceeds will be offered.

Among the Malikiyah (followers of the Maliki imam school), popular opinion which allows representation in cash as contained in the book of AlMajmu 'by Imam Nawawi (15/325):

Shaykh al-Islam Ibn Taymiyyah in Al Fatawa (31 / 234-235), narrated an opinion from the Hanabilah circles which allowed to represent in the form of money and the same thing was said by Ibn Qudamah in his book Al-Mughni(8/229-230).

Imam al-zuhri (d. $124 \mathrm{H}$.) argues that it is permissible to endow the dinar and the dirham by making the dinar and dirham as business capital and then the profits are channeled to mauquf 'alaihi (those entitled to receive the results of the endowments). (Abu Su 'Ud Muhammad, 199720-21).

Mutaqaddimin from the Hanafi school of law allows the endowment of dinar and dirham money as an exception, on the basis of Istihsan bi al-'Urfi, based on atsar Abdullah bin Mas'ud ra: "What is considered good by Muslims is in the view of God bad" (Wahbah al- Zuhaili, 1985, juz VIII: 162). 
Abu Tsaur narrated from Imam Shafi'i about the ability of waqf dinar and dirham (money). (Al-Mawardi, Al-Hawi al-Kabir, 1994, juz IX: 379).

On 28 Shafar 1423 H. 11 May 2002 AD, the Indonesian Ulema Council Fatwa Commission has proclaimed the endowment of endowments of money and is included in the sense of money as securities.

Murat Cizaka (1998) states, cash waqf has also been received in Turkey, Egypt, India, Pakistan, Singapore, Iran, and other countries. In Indonesia, the Indonesian Waqf Tube Dompet Dhuafa pioneered the issuance of the Cash Waqf Certificate (SWT) for the first time focused on realizing Free health services (LKC), the Indonesian free SMART Ekselensia school, the Institute of Independence, and others.

\section{CONCLUSION}

Istihsan is one methodology that can be used in restoring syariah law '. Apart from debates among the scholars regarding this methodology, in fact the istihsan methodology was seen as important in analyzing a contemporary economic activity to draw legal conclusions, including productive waqf models which indeed became a new discourse in terms of representation. This paper has compared the istihsan method related to cash waqf. The results showed that endowments of legal cash are permissible and acceptable in many countries which implement them according to the istihsan bi al-'urf approach (the good of following the habits of the local people). 


\section{Fitrah \\ $\triangle$ Jurnal Kajian Ilmu-ilmu Keislaman \\ Vol. 6 No. 1 June 2020}

\section{REFERENCES}

Abi Ishaq al-Syatibi, al-Muwafaqat fi Ushul al-Syari'ah, Juz I (Kairo: t.th).

Abū al-Hasan 'Abd Allāh bin Miftāh $(1340 \mathrm{H})$, al-Muntaza' al-Mukhtar min alGhayth al-Midrar al-Miftah li Kama'im al-Azhar fi Figh al-A'immah alAtar, j. 3. Mesir: al-Ma'ārif.

Abū Bakr bin Muhammad Taqy al-Dīn (t.t), Kifayat al-Akhyar fi Hali Ghayat alIkhtisar. Kairo: Ahmad bin Sa'id Nabham;

Abū Muhammad bin 'Abd Allāh bin Ahmad bin Muhammad bin Qudāmah (1972), al-Mughnī li Ibn Qudamah, j. 6. Kairo: Maktabah al-Qāhirah.

Abu Su'ud Muhammad (1997), Risalah fi Jawazi Waqf al-Nuqud. Beirut: Dar Ibn Hazm.

Ahmad bin Qāsim al-Unsi al-Yamanī al-Sun'ānī (1947), al-Taj al-Madhab li Ahkam al-Madhabì, j. 3. Kairo: 'Īsā al-Bābi al-Halabī.

Al-Māwardī (1994), al-Hāwi al-Kabìr, j. 9. Beirut: Dār al-Fikr.

Al-Munāwī (t.t), Taysīr al-Wuqūf 'ala Ghawamidī Ahkam al-Wuqūf, direkod dari perpustakaan al-Azhar, nomor: 709/5581.

Al-Sharkhasī, (w. 490-500H), al-Mabsūt, j. 12. Mesir: al-Sa'ādah.

Amir Syarifuddin, Ushul Fiqh, Jilid II (Cet. I; Jakarta: Logos, 1999).

Badrān Abū al-'Aynayn Badrān (1982), Ahkām al-Wasaya wa al-Awqaf. Kairo: Mu'assasah Shabāb al-Jāmi'ah.

Departemen Agama Republik Indonesia (2005), Panduan Pemberdayaan Tanah Wakaf Produktif Strategis di Indonesia. Jakarta: Direktorat Pengembangan Zakat dan Wakaf.

Departemen Agama Republik Indonesia (2006), Strategi Pengembangan Wakaf Tunai di Indonesia. Jakarta: Direktorat Pemberdayaan Wakaf.

Didin Kaem (2007), "Wakaf Produktif: Sebuah Alternatif Untuk Pemberdayaan Ummat", http://www.halalguide.info/content/view/904/46/, 27 Juni 2020.

Ibn Hāshim (t.t), Sīrah al-Nabī s.a.w., juz. 3. Mesir: Maktabah Kāherah. 
Ibn Manzūr Muhammad Ibn Mukarram (1990), Lisan al-'Arab, j. 9. Beirut: Dār alFikr.

Ibn Taimiyah (1386 H), Fatawa al-Kubra, j. 31. Beirut: Dar al-Ma'rifat.

Ja'far bin al-Hasan bin Abī Zakariyyā Yahya bin al-Hasan (w.676 H), Sharai' alIslam, j. 1. Beirut: Dār Maktabah al-Hayāh.

Mahmud bin Bakyr (2003), Kamus Bahasa Indonesia Nusantara, c. 1. Negara Brunei Darussalam: Dewan Bahasa Dan Pustaka Brunei.

Mohamad Rizki (2003), "Efek Multiplier Wakaf", http://www.geocities.com/comment indonesia/commentmr009.htm, 27 Juni 2020.

Muhammad 'Abīd 'Abd Allah al-Kabisī (2004), Hukum Wakaf. Ahrul Sani Faturrahman (terj.). Jakarta: Dompet Dhuafa Republika dan IIMaN Press.

Muhammad Abū Zahrah (1959), Muhad arat fi al-Waqf. Beirut: Jāmi’ah al-Dār alFikr al-'Arabī.

Muhammad bin Isma'il Abu 'Abd Allah al-Bukhari al-Ju'fi (1987), al-Jami' al-Sahih al-Mukhtasar, 6 j., Kitab al-Shurut, Bab al-Shurut fi al-Waqf, no. Hadith 2586. Beirut: Dar Ibn Kathir.

Muhammad bin Isma'il Abu 'Abd Allah al-Bukhari al-Ju'fi (1987), op. cit., Kitab al-Zakat, Bab Ithmu Mani'u al-Zakat, no. hadith 1338. Beirut: Dar Ibn Kathir al-Yamamah.

Nasroen Harun, Ushul Figh I (Cet. I; Jakarta: Loogos, 1996).

Roy Hendrajanto (2004), “Luncurkan Reksadana Wakaf", http://www.republika.co.id/koran detail.asp?id=168931\&kat id=105 \&kat id1=147\&kat id2=, 27 Juni 2020.

Sayyid Sābiq (1971), Fiqh al-Sunnah, j. 3. Kuwait: Dār al-Bayān.

Umar Hubeis dan A. Yazid, Figh al-Lighah al-"Arabiyah, Jilid II (Cet. IX; Surabaya; Pustaka Progresif, 1985).

Uswatun Hasanah (2005), “Wakaf Wang, Nazir, dan Penanggulangan Kemiskinan", http://www.republika.co.id/online detail.asp?id=207307\&kat id=256, 27 Juni 2020. 


\section{Fitrah \\ $\triangle$ Jurnal Kajian Ilmu-ilmu Keislaman}

Vol. 6 No. 1 June 2020

Wahbah al-Zuhaylī (1985), Fiqh al-Islamī wa Adillatuhu, j. 8. Damshik: Dār al-Fikr.

Wakaf Saham (2006), "Berbagi Keuntungan Dengan Allah", Tabung Wakaf Indonesia Magazine, edisi Ramadhan $1427 \mathrm{H}$.

Yayasan Penyelenggara Penterjemah (1993), al-Quran dan Terjemahnya. Jakarta: Intermasa. 